\title{
Hyperplastic polyposis syndrome: a call for broader diagnostic criteria
}

\author{
Matthew F Kalady*, Awad M Jarrar, Lisa LaGuardia, Margaret O'Malley, James M Church \\ From 13th Annual Meeting of the Collaborative Group of the Americas on Inherited Colorectal Cancer \\ Honolulu, Hawaii, USA. 16-17 October 2009
}

\section{Background}

Hyperplastic Polyposis Syndrome (HPS) is a rare disease characterized by multiple or large hyperplastic polyps and carries an approximately $40 \%$ lifetime colorectal cancer risk. Although a genetic basis has not been established, HPS is believed to be a heritable syndrome and is diagnosed by clinical criteria as set forth by the World Health Organization (WHO). Based on clinical experience, we hypothesized that WHO criteria may be narrowly restrictive and misses some patients with an increased malignancy risk.

\section{Methods}

For this study, HPS was defined by meeting at least one of the following criteria: 1 ) $\geq 20$ HPs anywhere in the colon, 2) $\geq 5$ HPs proximal to the sigmoid colon, 3) $\geq 2$ HPs at least $10 \mathrm{~mm}$ in size, 4) any HPs and a 1st degree relative with HPS. Colonoscopy and pathology databases were retrospectively reviewed for patients meeting criteria. Patient demographics, colonoscopic findings, and personal and family history of cancer were recorded.

\section{Results}

Sixty patients (38 males, 22 females) meeting at least one of the above criteria were included. Only 19 of these 60 patients (32\%) also satisfied WHO criteria for HPS. Results are summarized in Table 1. Importantly, of the additional 41 patients only meeting the broader criteria, $27 \%$ had a personal history and $44 \%$ had family history of colorectal cancer. This group also had extracolonic malignancies including breast, lung, prostate, and testicular cancer.

\footnotetext{
* Correspondence: kaladym@ccf.org

Department of Colorectal Surgery, The Sanford R. Weiss Center for Hereditary Colorectal Neoplasia, Digestive Disease Institute, Cleveland Clinic,
} Cleveland, Ohio, USA
Table 1

\begin{tabular}{|c|c|c|c|c|c|}
\hline \multirow[t]{2}{*}{ HPS Criteria } & \multirow[t]{2}{*}{$\mathbf{N}$} & \multicolumn{2}{|c|}{$\begin{array}{c}\text { Colorectal Cancer } \\
\text { History }\end{array}$} & \multicolumn{2}{|c|}{$\begin{array}{c}\text { Other Cancer } \\
\text { History }\end{array}$} \\
\hline & & Personal & Family & Personal & Family \\
\hline WHO & 19 & $5(26 \%)$ & $4(21 \%)$ & $8(42 \%)$ & $7(37 \%)$ \\
\hline Only New Criteria & 41 & $11(27 \%)$ & $18(44 \%)$ & 9 (22\%) & 11 (29\%) \\
\hline All Patients & 60 & $16(27 \%)$ & 18 (37\%) & $12(23 \%)$ & $18(30 \%)$ \\
\hline
\end{tabular}

\section{Conclusion}

HPS is associated with a personal and familial risk of colorectal cancer and other malignancies. Applying broader definitions identifies an additional population of patients with increased personal and familial cancer risk. More inclusive criteria should be used until a genetic basis of disease better defines cancer risk.

Published: 25 May 2010

doi:10.1186/1897-4287-8-S1-P8

Cite this article as: Kalady et al:: Hyperplastic polyposis syndrome: a call for broader diagnostic criteria. Hereditary Cancer in Clinical Practice 2010 8(Suppl 1):P8.

Submit your next manuscript to BioMed Central and take full advantage of:

- Convenient online submission

- Thorough peer review

- No space constraints or color figure charges

- Immediate publication on acceptance

- Inclusion in PubMed, CAS, Scopus and Google Scholar

- Research which is freely available for redistribution

Submit your manuscript at www.biomedcentral.com/submit
C Biomed Central 